\title{
Democratic Spirits in Dayaman Shumsher's Life and Writings
}

\author{
Ramji Timalsina \\ Tribhuvan University, Kāthmāndu, Nepal \\ Email: ramjikoshi@gmail.com
}

How to cite this paper: Timalsina, R. (2020). Democratic Spirits in Dayaman Shumsher's Life and Writings. Advances in Literary Study, $8,35-45$.

https://doi.org/10.4236/als.2020.82004

Received: January 15, 2020

Accepted: March 6, 2020

Published: March 9, 2020

Copyright (C) 2020 by author(s) and Scientific Research Publishing Inc. This work is licensed under the Creative Commons Attribution International License (CC BY 4.0).

http://creativecommons.org/licenses/by/4.0/

(c) (i) Open Access

\begin{abstract}
What is the effect of a writer's lifestyle on his/her writings? This article tries to show how they are integrated with an analytical example of Nepali freedom fighter and historical novelist Dayaman Shumsher Rana's life and writings. Based on his beliefs on society, individual and democracy and the lifestyle, he followed, and their portrayal in his novel Pratibaddha [Committed] (Rana, 1981), this analysis is made. Rana lived an exemplary committed life of a democrat and always worked for the establishment and promotion of democracy and its spirit and culture. In his novel Pratibaddha, the same commitment is given a fictional touch through the portrayal of the life of its protagonist and other components of the text. The study is based on the exploratory readings on Rana's life and the basic principles of democratic spirit, and application of its major findings in the study of the novel in question. Finally, it is found that a writer's lifestyle has a great role in the creation, and Rana's Pratibaddha is its good example. The research has found that Dayaman was born in the aristocratic Rana family; but he grew as a revolutionary in his youth. So he fought against his own family reign and the then despotic rulers of Nepal. Once democracy was introduced in the nation, he worked as a model democrat. The main character of the novel under this study also exhibits the similar qualities of a democrat.
\end{abstract}

\section{Keywords}

Life Style, Democratic Spirit and Culture, Commitment, Historical Novel

\section{Introduction}

Dayaman Shumsher Rana is a freedom fighter, democrat and a historical novelist from Nepal. His fictional creations are based on Nepali history in relation with the social consciousness and individual's role in its making. Critic Krishna 
Gautam finds the elimination of the line between the writer's (Rana's) life and his fictional characters and thinks that Roland Barth's idea of the death of the author is not an appropriate theory in this connection (Gautam, 2008). Researcher and critic Govinda Raj Bhattarai also finds the connection between his life and writings. Bhattarai argues that Rana worked to make the Nepali people conscious about their rights, duties and democracy both in his life and through his writings. His focus in both was on the establishment and promotion of democratic values, commitment to it and the related ideals. Bhattarai further claims that Rana used the power of freedom and democracy in literature, and ultimately got his own power through literary creation (Bhattarai, 2011). Here lies the value of Rana's life and writing, and the need to study his novels in this light.

A close connection between literature and politics can be understood with the help of reading Rana's life and creations. Rana himself thought that without the promotion of language and literature, a nation cannot be developed. Critic Krishnachandra Singh Pradhan declares that Rana did a more important job than politics can do through his literary creations. He could not do so much being just a cadre of Nepali Congress (Pradhan, 2008). So thinks Krishna Gautam and explains that Rana always stands against the attempts of prioritizing feudalism and writes in favour of democracy and reformation (Gautam, 2008). It is as per Rana's idea that literature and education develop the social consciousness that is the base of both the republic and democracy. He realized that such consciousness was necessary when he was taken to jail at the beginning of the party-less Panchayat System, and it increased his commitment to literary creations. So, Rana firmly believes that we need to promote literature for the development of peace in the nation, in the society; the present growth of restlessness, violence and chaos is because of our disregard for literature (Neupane \& Pande, 2008). It shows Rana's commitment to promoting good social qualities both in his life and writings.

\section{Connection between Literature and Democratic Values: A Review of Literature}

There is a close connection between literary creations and democratic values. Democratic values are related to the promotion of basic human rights. Democracy is "a way of life whose purpose is to enable people to achieve spiritual autonomy, live in mutual respect, and enjoy happiness." It is also related to the health of the democratic polity that "depends on remembering who we are, individually and collectively." So, it helps in the promotion of true humanity and invites those "who have been forgotten, violated, diminished, shut out of the human circle" to join the true human society once more (Bogen, 2010). Democratic spirit does not let anyone be outside the boundary of justice and equality.

Similarly, Juwon Sudarsono argues that democratic spirit is related to "all five dimensions of human rights-civil, political, economic, social and cultural" that are "interrelated, indivisible and balanced" (in IPU, 1998). It envisions de- 
mands $\cdot 221 \quad 2 \quad 2$ and promotes the growth and development of democrats who, according to Victor Massuh, have "a high degree of rationality in the world dominated by irrational stimuli of passion, propaganda, sports and televised image" and who work for the empowerment of ordinary people who have "rationality, moderation and respect for others". Massuh further argues that such a democrat is "an exceptional social product: he is an elitist, who works within democratic institutions to preserve their purity and best ensure their survival". He believes that in the present world where "democracy has ceased to be an ideology and has now become a universally recognised truth" the promotion of democratic spirit has become a basic social necessity (in IPU, 1998). So, writings of a democrat should consist of and promote democratic spirit. Here lie the value and use of democratic spirit in literature.

Literary creation can carry on and give expression to democratic spirit as

Democracy, in any of its meanings, requires the existence and free exercise of certain basic individual and group rights. [...] These basic rights are inter alia: life, liberty, and property, due process of law, equality; non-discrimination, freedom of expression and assembly, and judicial access and review (Bassiouni, 1998).

Freedom is the basis of all democratic spirits because it "is creative"; it "makes the human being 'generic'-it is the first act of the universal which is valid anywhere at any time"; and it helps democracy simply to "become the ideal of the ordinary man" and in return "democracy gives it the means to become something other than a solitary attempt" (in IPU, 1998). The second quality of democratic spirit literary creations possess is the dream for equality. The guarantee of this condition in a society is possible, according to Alaine Touraine, only when there is "[r]estriction of the power of the State, autonomy of social actors and awareness of citizens" Touraine further stresses that "these are the three conditions for the existence of democracy, or more precisely the three principal manifestations of the existence of democracy" (in IPU, 1998). These two are the basic features that connect literature and democratic spirit.

To reach this level of equality, there should be acceptance, inclusion, participation and the space for an individual's dignified existence. It is because "true democracy means nothing less than the ongoing inclusion of all persons in its process and promise" (Bogen, 2010). Similarly, "participation is a core function of democratic leadership" that can promote "productivity, satisfaction, involvement, and commitment" (Choi, 2007). At the same time, democratic spirit is a certain totality of certain attitudes and commitments. It is a "productive attitude of right kind" that ensures the "collective $[\ldots]$ honour of the nation $[\ldots]$ (and) the honour of the citizen" (Appiah, 2013). In this regard, a literary creator's role is to develop and popularize the basic ideal of democracy that

aims essentially to preserve and promote the dignity and fundamental rights of the individual, to achieve social justice, foster the economic and social development of the community, strengthen the cohesion of society 
and enhance notional tranquility, as well as to create a climate that is favorable for international peace (IPU, 1998).

The way democracy is a rejection of traditional closed systems of thought and centrality of power, in literary creations democratic spirit is connected with the rejection of closed forms, elite diction and traditional grammatical pattern. Patrick Redding discusses how Whitman connected his sense with the form of poetry: "associating democracy with the rejection of traditional poetic meter and rhyme [...] is linked directly to his sense of freedom from the "arbitrary" authority of monarchy and aristocracy". He further clarifies that "the absence of "rhyme and uniformity" indicates a poet's commitment to the free expression of (human) nature. The democratic citizen was entitled to "free growth" in his private imagination just as in the public world of politics". He discusses how Whitman's Leaves of the Grass maintains democratic spirit in terms of style: "the poems articulate democratic beliefs not just through a consistent facet of style, but also by reflecting the complex arguments, images, and shifts in tone and rhythm by which the voice of democracy declares itself on and off the page" (Redding, 2010). Similarly, the democratic style of literature is connected with " $[t]$ he "demotic", the daily language of ordinary people" as "the primary aesthetic issue, and with the decline in formal change" (Adler, 2012). These qualities are found in almost all of literary creations with democratic spirit.

\section{Research Approach}

Among the genres in literature, novel is a democratic genre from the time of its inception. It has been representing multiple dimensions of human society. Critics think that Dayaman Shumsher's novels are such examples. His major novel Seto Bagh [ White Tiger] is the expression of the novelist's commitment to the parliamentary democracy and liberalism (Bhattarai, 2008). Next critic Ramdayal Rakesh discusses the use of history in Rana's novels and concludes that there is a voice of political structure within historical subject matter. As the novelist is the advocate of democracy, he presents the voice for political ideology and philosophy through fiction (in Neupane \& Pandey, 2008). So, democracy and Rana's writing are interconnected. On this backdrop, this article tries to analyse the connection between his life and writings keeping the democratic spirit at the centre. To explore this relation, the following research questions are set:

- What democratic ideals are at the base of Dayaman Shumsher's lifestyle?

- How are democratic spirits expressed through the theme, characterization, atmosphere and plot of the novel Pratibaddha [Committed]?

- Why are the lifestyle and writings connected?

With the use of the basic norms of democracy as discussed in the review of literature in the previous section of this article, the analysis of different aspects of the novel is made so as to show how a work of fiction can carry on democratic spirit. The research questions are, thus, answered. 


\section{Rana's Life and Democratic Spirit}

Hemangraj Giri has written a book on Rana's devoted life and fight for freedom and democracy. Dayaman Shumsher Rana was born in the then ruling clan of the Ranas. Ranarchy had put the king under control and ruled the nation at their will. Their mouths were the source of law; and their desires were taken as God's wishes. Dayaman was in a post of Second Lieutenant in the military as by birth the Ranas had their posts in the army. But he never liked the way the nation was running. When he saw how the last Rana Prime Minister Mohan Shumsher treated B. P. Koirala, the then leader of the democratic movement, in the jail, he decided to work against the Ranarchy to establish democracy in the nation. He wrote his first novel Basanti to reveal the inhumanity inside the palaces of the Ranas. Its readers were motivated to work for the establishment of democracy in the nation. Historically, he led the first anti-Rana rally at Kathmandu.

For all these activities he could have been punished with hanging. He did not care about it because for him the order of his conscience and the freedom of people were more important than any post and even life. He was put into the jail. As per his desire and actions, in 1950, the Ranarchy was overthrown with people's movement and democracy was established in Nepal. After the revolution, he even made a better contribution to the democratic system. The first democratic government wanted his help to remove the unwanted and unskilled Ranas from different posts in the army. He convinced them to leave the job and support the nation. Then he himself resigned from the post despite the king's request for not to resign because he thought it was not a moral act to convince the other to leave the job and to hold it for himself. All of them were appointed with the same process. He accepts that then he became a porter. It was his choice; so he did it (Giri, 2008). This shows how moral and committed to the principles he was.

After that, he worked as the chairperson of Lalitpur district committee of $\mathrm{Ne}$ pali Congress, the party that led the movement to establish democracy. After the first elected government of the nation got the helm of the nation in 1958, he supported it to bring the democratic principles in practice. The government led by the Prime Minister B. P. Koirala decided to end Birta i.e. the ownership of the land given to the elites by the Ranas and the Shahas. It was Dayaman Shumsher who transferred the ownership of his Birta in Rautahat to the names of the people who had been tending it; and consequently he became landless. In later dates, this decision did not make him sad; instead, he was happy to work as per his democratic principles.

Giri (2008) reports his opinion regarding these activities and their consequences. He was happy to fight for democracy and freedom. His whole life was spent in rallies, mass meetings, conferences and jails. But he never felt dissatisfaction and pain because these were the sure consequences for a freedom fighter of his time. But when democracy was in function, he never wanted to have any benefit; and never regretted what he had done. He felt that there was a danger for de- 
mocracy from King Mahendra and reported it to the then Prime Minister B. P. Koirala who did not believe him. But ultimately, King Mahendra ended the democratic system with a royal coup. This shows how farsighted he was in politics.

In an interview with R. M. Dangol and Dhanaraj Bhattarai collected in Neuapane and Pandey (2008), he has expressed his evaluation of his life and writing. He says: I used my pen against the autocratic tyranny of the Ranas. Consequently, I lost all my properties; but I had no regret because it was as per my desire. My habit of taking the decision as per my conscience caused it all. Then he reports that his novels are also written for the promotion of democracy in which people will be the highest source of power. He wanted it and so through his novels he went on declaring that people should get democracy. By the time, he was ninety years, he felt satisfied because by then not only the democracy but the republican system was established in Nepal. This shows his commitment to democratic principles both in the society and his own individual life.

\section{Democratic Spirit in Pratibaddha}

\subsection{Background of the Creation}

Pratibaddha is a novel set in autocratic Panchayat period (1960-1990) of Nepali politics. It was published in 2034BS/1977. So it has been written with the effect of B. P.'s the latest principle of national agreement and coordination that he propounded one year before the novel was published. B. P. Koirala had returned to Nepal from his years-long exile in India with this principle and slogan. So, this novel, to some extent, reads like a political manifesto of the then Nepali Congress. Pokharel further claims that this novel presents the political disfigurement and absurdities in the Panchayat system and how the cadres of Nepali Congress and other parties that wanted to reestablish democracy struggled for it (Pokharel, 2011). These observations connect the novelist's life and democratic principles the novel has advocated.

Critic Bhawani Ghimire (1981) has found that there is abandonment for love and devotion to principle at the centre of the novel. Symbolically, the novel presents the atmosphere that hinders the connection between the king and the people. But the novel advocates that their connection, love and cooperation are necessary and sure to come into effect. This is done with the love relations of two pairs in the form of the main story of the novel. In many places Dilip Parajuli, the male protagonist of the novel, highlights the value of the struggle he and his friends have undertaken. Once he has a dream in which he is an elected member of the parliament where there is a discourse between the government and the opposition benches on the need of the nation following democratic system. These incidents show the intermingling of the dream of the protagonist, that of their leader B. P. Koirala and the novelist himself.

\subsection{Democratic Spirit in the Storyline and Scenes}


The main story line of the novel has also followed the democratic principle through its female protagonist Thuli or Rupadevi Shrestha. Despite the poverty of her family, she is a cultured and committed young lady. She is in relation with Dilip, and is committed to it throughout life. Once her virginity is threatened by a chief official saint of a temple, she happens to meet Dilip in a state of flight with a bomb. She manages to have a night with him and without his knowledge in his unconscious delirium she gets her virginity broken by him and conceives a baby. Later, she is sold to a brothel in Banaras, but manages to save herself to meet Dilip in a police station back in Nepal. She gives birth to a baby in front of Dilip.

One day she replaces Dilip in custody because he has to go for a party mission that is to be completed that night. Accidently, the drunken police officers mistake her as Dilip asleep in custody; and they take her to the jungle; tie her on a tree; and finally shoot her. Before she dies, Dilip arrives; meets her; and puts his blood as sindur and marries her before she takes the final breath on his lap. She dies fulfilled. It shows that the committed relation and the consequent actions will lead to one's goal in future. It symbolically suggests the need for such commitment in the part of the freedom fighters to their spirit of democracy and necessary actions for this. Rana himself was one of these fighters for democracy. It is how his life and the life of the characters in the novel are similar. After thirty-one years of this writing, Rana could feel that the commitment of the Nepali people and their leaders to reestablish democracy has got its goal achieved. He thinks truth is always victorious though it takes time (Giri, 2008). This also shows that his life has entered into his creation.

All the scenes portrayed in the novel are used to show the condition of a nation in the absence of a democratic system. There are the stories of different aspects of the Panchayati polity and the struggle for democracy. The democrats have to live hiding their identity; whereas, the thieves are presented as people-friendly democrats by the rulers of the time. The followers of democracy are compelled to accept the crimes done by others. The politicians cannot speak the truth. The Prime Minister does not know the ground reality of his immediate society; and is in the government not as people's hope but just as a guest to work in the order of some unknown force. Journalists are not able to write correct news. And the followers of democracy are under threat and rumours. These incidents and realities are what the novelist experienced in his life; did not like them; and wanted to change the situation. The same is portrayed in the novel so as to make the readers feel what the novelist feels.

\subsection{Democratic Spirit in Characterization}

The spirit of a democrat is shown even in the selection of the characters in the novel. There are three types of characters. The first type is created to show the then social reality in Nepal. They are the feudal ones: the priest, Kailash, Krishna, the brothel owner and Prime Minister Prakash. They have the supporters 
who make the second type: a clerk, Thuli's parents (teacher and his wife), Sharada, Himmat, Bhimdev, Madhav, old woman at Banaras, her daughter and Gulab (a whore). These characters are used as the means of fulfilling the desires and plans of the feudal lords for whom pleasure is everything in life whatever are the means to achieve it. Different from these two types in orientation of life are the third type: Thuli, Dilip Parajuli and General Raut. They are committed to humanity, democracy and duty. The Nepali society during the Panchayat Period was the totality of these types of characters.

The time was in the predominance of the first type of characters. The priest represents the mean but prominent gamer behind the scene in the society of the time (Pokharel, 2011). He is busy with the whores; but chant "Ram Ram" all the time. The society takes him to be a great saint who can help the people in time of difficulty. The novelist has used him to symbolize the party-less autocratic Panchayat rule. The king and the other supporting rulers make the publicity of Panchayat as the solution to all pains and problems of the Nepali people; but exactly it is just like the same priest's actions. Both the priest and the Panchayat system have two faces: one to show, and the other to hide and use for benefit including undue pleasure.

The way the priest always focuses his gaze on young women's breasts; so do the Panchayat supporters: their focus is not on the development of the Nepali society, but on the accumulation of wealth and other means of pleasure. The priest lures Thuli to provide her everything if she allows him to use her body. This symbolically shows how the Panchayati rulers lure many supporters of democracy. Thuli is never ready to believe him and be deterred from her commitment. This shows the committed life of the freedom fighters. Finally, the novel shows a terrible end of the priest. It indicates that Panchayat is not going to last long. Such an autocratic system is not good even for the autocrats themselves. The autocrats of the world history had very terrible ends. It highlights the value of democratic system that can be good for both the rulers and the people.

The other characters in the first type also have the similar behavior and meet the same fate at the end. The brothel owner believes that there is no sin or virtue in this world; if there is something valuable, it is the money and money only. Money can define one honest, intellectual and virtuous. Gulab is the next character who represents the hollowness of the heart. She was a sex worker by force in the beginning, but later she manages to be the minister's wife. Then she acquires the feudal character. She is presented in the novel to show the contrast with Thuli. Thuli is satisfied even in great troubles because she knows she is committed to the good cause for humanity; but Gulab is always dissatisfied even amid wealth and pleasures. She finally thinks: Her life in the brothel was far better than as a minister's wife who has to involve all the time in inhuman conspiracies. She has forced Thuli to hand her child from Dilip to make it her (Gulab's) son. It is a symbol of how the Panchayat System forcefully took the baby democracy and tried to show it as its own child. But such a lie cannot last long. The 
rulers themselves have found the hollowness of their heart.

Similar satire is found in the name of the Prime Minister. His name is Prakash [The Light]; but he himself is in the shadow. Characterization of the ministers in his cabinet is also similar. Many of them are the thieves, human traffickers and inhuman in their activities. They have no principle, commitment and ideology. Their supporting officials are also the corrupt people who are ready to do anything for the sake of money and pleasure. Krishna is one such police officer who was guided by revenge motive, the show of ego; and so devoid of necessary qualities of a government official such as righteousness, patience, liberalism and wisdom. These characters show the causes and effects of an autocratic system, and so highlight the need and value of democratic system to manage a nation. Himmat, Bhimdev and Gulab are the characters who are grown under the injustice of feudalism; and so once there is a chance, they also turn themselves into the same. Feudalism and autocratic systems give birth to the similar misguided practices. So, they are bad not only for the present, but also for the future of the society.

The second type is that of the escapists. The couple of the teachers or Thuli's parents are such characters. They do not care about the values and duties of their life; instead, they surrender everything in front of the feudal. If a teacher in a society has such an attitude to life, what may be the future of the society? But, in the same second type there are some characters who are compelled to support the feudal's injustice; but once they get the chance they use their human face. The clerk, Sharada and Inspector Madhav are such characters. The novel has the sense that we need to promote good qualities even among the supporters of the bad rulers so that once there is need, we can use them for the betterment of the society. Once such characters come out of compulsion and illusion, they will work well.

The third type of characters represents the quality of good humans, the democrats and the novelist himself. The relation between Dilip and Thuli (Rupa Devi) and their actions show how democrats should work. Dilip seems to be the shadow of the novelist himself. He is committed, energetic and sensible; but he is full of pain in the heart because he could not do anything to free the people from the shackles of the feudal autocrats. This pain makes him more committed to his aim in life. He knows that the society is full of injustice because of the lack of equal distribution of the means. Though he is against the system, he respects the king. He thinks the coordination between the king and the people will be helpful to solve all these problems. This is what B. P. Koirala, their party Nepali Congress and its cadres including the novelist thought at that time of Nepali history.

Dilip is a believer and symbol of a peaceful revolution (Pokharel, 2011). He practices his principles in his lifestyles, too, just like the novelist himself. He thinks that he is a property of the society; so, his individuality is already socialized. Individual happiness is not the matter of prime concern for him. He thinks that he should not be engaged in family affairs and love relation because the 
mother nation is appealing him to end the injustice and mistreatment in the society. These beliefs and activities prove him to be an ideal democrat, freedom fighter and a committed individual.

The main character of the novel is Thuli. Her names go on changing according to the situations: Kumari Shrestha, Rupa Devi Shrestha, Bhagindevi, and Kumari Pandey. She is an epitome of tolerance, commitment, love, good will and devotion. She is a complete and ideal human being. She is sure to get to her destination: Dilip's love! She struggles to save her virginity and later purity for Dilip. Her struggles show how difficult it is to live as a good person in a corrupt society. But she is able to sustain her existence with commitment. Devotion and commitment to one's ideal are the ultimate weapons to fight against the bad elements in a society. For a successful life of both the society and individual, the valuable things are not concrete objects but spiritual fulfillment. She thinks it is her fortune to be killed in place of Dilip. What a great devotion it is! These are the fictionalizations of the novelist's beliefs.

\section{Conclusion}

The novel Pratibaddha shows how the novelist's life is a model for his fiction. Dayaman Shumsher Rana lived a life of an ideal democrat. So, in all his novels he pleads for the same in other individuals. Among all his creations, Pratibaddha is a picture of the Nepali society during the Panchayat Period. It portrays both aspects of the then society: injustice done by the inhuman rulers and the commitment of the freedom fighters for a nice future. The bad characters in the novel and their activities are what the novelist has observed in the society of the time; and the good characters and their activities are the expressions of his own lifestyles and beliefs. Devotion to one's duties and commitment to an ideal cause are what make a man emotionally satisfied and successful in life. It is possible only in a society that is developed with democratic norms. An autocratic political system is good neither for its rulers, nor for the immediate society nor for the future of humanity. These are the beliefs of the novelist; and the same are reflected through the story, characters, environment and other aspects of the novel. This study shows how the life of a writer can be the base of his/her creative writings. Rana's other novels and the writings by other creators also can be studied from this perspective.

\section{Conflicts of Interest}

The authors declare no conflicts of interest regarding the publication of this paper.

\section{References}

Adler, J. A. (2012). The Poetry of Democracy. http://sadredearth.com/the-poetry-of-democracy

Appiah, K. A. (2013). The Democratic Spirit. Dædalus: Journal of the American Academy of Arts and Sciences, 142, 209-221. https://doi.org/10.1162/DAED_a_00214 
https://www.amacad.org/content/publications/pubContent.aspx?d=1055

Bassiouni, C. (1998). Towards a Universal Declaration on the Basic Principles of Democracy: From Principals to Realization. In C. Bassiouni, D. Beetham, J. M. Fathima Beevi, A. K. Boye, A. E. Mor, H. Kubiak et al. (Eds.), Democracy: Its Principles and Achievement (pp. 1-20). Geneva: Inter-Parliamentary Union.

Bhattarai, G. R. (2008). A Survey of Seto Bagh and Rereading Magic Realism. In C. Neupane, \& H. Pandey (Eds.), Aakhyaankaar Daayaman [Novelist Dayaman] (pp. 79-104). Kathmandu: Dayamanshamsher Rana Sahityik Pratishthan.

Bhattarai, G. R. (2011). The Value of This Historical Study Will Always Be Attached with the Glory of Dayaman Shumsher. In T. Pokharel (Ed.), Historical Novels: Theory and Form. Kathmandu: Dayamanshamsher Rana Sahityik Pratishthan.

Bogen, M. (2010). This Noble Experiment: Developing the Democratic Spirit. http://www.ikedacenter.org/ikeda-forum/2010-democracy

Choi, S. (2007). Democratic Leadership: The Lessons of Exemplary Models for Democratic Governance. International Journal of Leadership Studies, 2, 243-262.

Gautam, K. (2008). Dayaman Shumsher in Historical Discourse. In C. Neupane, \& H. Pandey (Eds.), Aakhyaankaar Daayaman [Novelist Dayaman] (pp. 4-9). Kathmandu: Dayamanshamsher Rana Sahityik Pratishthan.

Ghimire, B. (1981). Background. In D. Rana (Ed.), Pratibaddha [Committed] (2nd ed.). Kathmandu: Ratna Pustak.

Giri, H. (2008). From Second Lieutenant to Nakhkhu Jail: Biography of Senior Novelist Dayaman Shumsher Rana. Kathmandu: Oxford International Publication.

IPU (1998). Democracy: Its Principles and Achievement. Geneva: Inter-Parliamentary Union.

Neupane, C., \& Pandey, H. (2008). Aakhyaankaar Daayaman [Novelist Dayaman]. Kathmandu: Dayamanshamsher Rana Sahityik Pratishthan.

Pokharel, T. (2011). Aitihaasik Upanyaas: Siddhanta Ra Swarup [Historical Novels: Theory and Form]. Dayamanshamsher Rana Sahityik Pratishthan.

Pradhan, K. (2008). This Way Dayaman Shumsher Became a Novelist. In C. Neupane, \& H. Pandey (Eds.), Aakhyaankaar Daayaman [Novelist Dayaman] (pp. 1-3). Kathmandu: Dayamanshamsher Rana Sahityik Pratishthan.

Rana, D. (1981). Pratibaddha [Committed] (2nd ed.). Kathmandu: Ratna Pustak.

Redding, P. (2010). Whitman Unbound: Democracy and Poetic Form 1912-1913. New Literary History, 41, 663-690.

http://www.jstor.org/stable/40983890 